\title{
The List tidal basin: a reference area for scientific research in the northern Wadden Sea
}

\author{
K. Reise ${ }^{1} \&$ C. Gätje ${ }^{2}$ \\ ${ }^{l}$ Biologische Anstalt Helgoland, Wattenmeerstation Sylt; D-25992 List, Germany \\ ${ }^{2}$ Landesamt für den Nationalpark Schleswig-Holsteinisches Wattenmeer, \\ D-25829 Tönning, Germany
}

The Wadden Sea ecosystem shows obvious signs of long-term change (cf. Wolff, 1992; Reise, 1994a; Fleet et al., 1994; Rösner et al., 1994). There has been an areal decrease in brackish reed marshes and salt marshes, in some regions also of mud flats, seagrass beds and mussel beds, a decline in populations of anadromous and large-sized fish, a loss of sessile organisms from the deep channels, an increase in algal blooms, benthic zoomass and several bird populations, and, in addition, various exotic species have been introduced.

In many cases the causes are still disputable. Major factors have been identified, such as embankments, climatic events, fisheries, pollution, eutrophication and bird protection. However, the interactions and relative contributions remain uncertain. This is becoming more and more of a problem, because a sound coastal zone management needs to base its decisions on convincing evidence.

To improve the situation, the governments of Denmark, Germany and The Netherlands agreed at the Sixth Trilateral Governmental Conference on the Protection of the Wadden Sea, held in Esbjerg 1991, to establish protected reference areas for scientific research in the Wadden Sea (CWSS, 1992). This subject was further elaborated at the 8th International Scientific Wadden Sea Symposium in Esbjerg 1993 on the theme 'Protection and zero-use nature reserves' (Frederiksen \& Dahl, 1994). Recently, reference areas have been proposed for the National Park Schleswig-Holstein Wadden Sea by Stock et al. (1996). Protection should involve keeping exploitation and disturbances away from reference areas as far as possible.

This would allow an ecological development free of these factors, thereby showing more clearly the effects of wide-scale processes such as eutrophication, pollution and climate change. In particular, comparisons between reference areas and the remaining region would become more and more rewarding as development proceeds in the absence of exploitation and local disturbances that accompany ongoing economic use. Reference areas constitute open-end ecological field experiments, and if there are more than two reference areas interspersed over the entire Wadden Sea, then statistical discriminant analysis may give further weight to the results of comparisons.

Monitoring of sediment stability, turbidity, biotic diversity and biomass is made useless when fishery or dredging affect these parameters to an unknown and variable 
extent. If overall trends are to be monitored properly, sampling sites and measuring devices have to be off-limit to artificial disturbances. The establishment of protected areas is an essential prerequisite for environmental monitoring and for the scientific analysis of the underlying causal relationships.

Tidal basins, defined as the watershed of a tidal inlet with its branching channels, exposed tidal flats and fringing salt marshes, are the most suitable spatial units for monitoring and research within the Wadden Sea. A tidal basin may be looked upon as a sharing system for sediments, organisms and dissolved substances transported mainly by the tidal currents. The internal exchange rates generally exceed the import/export rates with adjacent tidal basins, the North Sea, the land and the atmosphere.

These processes have been investigated by the interdisciplinary research project termed SWAP, abbreviation of 'Sylter Wattenmeer Austausch-Prozesse' (= Sylt Wadden Sea Exchange Processes), the investigated subject being delineated by its title. Previous results have been published in 'Helgoländer Meeresuntersuchungen' Vol. 48, No. 2-3, 1994. An integrated view on the morphodynamics and biodynamics of the List tidal basin will be summarized in a book entitled 'Ökosystem Wattenmeer: Austausch-, Transport- und Stoffumwandlungsprozesse' (Gätje \& Reise, 1997).

In this volume of 'Helgoländer Meeresuntersuchungen' (HM 51, 3, 1997), we present further information on the exchange processes and long-term ecological developments in the List tidal basin. Together with the aforementioned publications and previous studies, there are now about 450 scientific contributions describing the geology, hydrodynamics and biota of this meso-tidal backbarrier lagoon. Presumably, these provide more information on natural history than is available for any other tidal basin in the Wadden Sea.

The List tidal basin is part of the northern Wadden Sea. The latter ranges from Eiderstedt peninsula in the south to Skallingen peninsula in the north, and represents roughly one third of the entire Wadden Sea. This coastline faces the prevailing westerly winds; riverine influence is relatively weak; seagrasses and mussel beds are abundant. The List tidal basin is located in the centre of this northern Wadden Sea, and the DanishGerman border passes right through the area.

The List tidal basin is an embayment in the shelter of the islands Sylt and Rømø, and the watershed of the List tidal inlet is confined by two causeways connecting both islands with the mainland. This basin includes a wide variety of geological and biotic attributes: tertiary and pleistocene cliffs, migrant sand dunes, exposed sandy shoals, sheltered mud flats and salt marshes, an extensive belt of seagrass and an abundance of mussel beds, large numbers of eiders and shelduck feed in the area, and in the tidal inlet seals and harbour porpoises are numerous. About 2000 species of aquatic organisms have been recorded in the List tidal basin.

The exploitation of its natural resources has changed in the course of time. Fishery on ray was once important but the species has faded away. An oyster fishery collapsed because of overexploitation. Shrimp fishery was extensive but now has moved almost entirely to the adjacent North Sea. Mussel fishery, on the other hand, has greatly expanded since the $1980 \mathrm{~s}$ with $9.8 \mathrm{~km}^{2}$ assigned to mussel cultures. This is in conflict with the use of the List tidal basin as a reference area.

Reference areas are not only for scientific research and monitoring. At the same time they represent core zones for nature protection with a minimum of human interference 
(Reise, 1994b). The aim is for natural developments to unfold and adapt to arising conditions. These areas are neither living museums nor is it intended to manage them back to some pristine state. Natural processes should be free to develop irrespective of the actual course. However, it may very well happen that these core areas serve as nurseries for the recovery of damaged habitats and endangered populations.

Considering the representativeness, the geomorphic and biotic diversity, and the amount of scientific research already performed, we herewith propose the designation of the List tidal basin as a bilateral reference area of the northern Wadden Sea for the purpose of environmental monitoring and scientific research.

Acknowledgements. The project 'Sylter Wattenmeer Austausch-Prozesse (SWAP)' was funded by the Federal Ministry of Education, Science, Research and Technology (BMBF). SWAP was part of the joint project 'Ecosystem Research Wadden Sea', initiated and coordinated by the Regional Office of the National Park Schleswig-Holstein Wadden Sea. Several experts advised us in reviewing manuscripts. The secretarial help of Elisa beth Herre and the copy editing of Carol Berger are gratefully acknowledged. This is publication '10. 268 of the project "Ecosystem Research Wadden Sea".

\section{LITERATURE CITED}

CWSS, 1992. Sixth Trilateral Governmental Wadden Sea Conference, 1991. CWSS, Wilhelmshaven, $141 \mathrm{pp}$.

Fleet, D. M., Frikke, J., Südbeck, P. \& Vogel, R. L., 1994. Breeding birds in the Wadden Sea 1991. Wadden Sea Ecosyst. 1-1994, 1-108.

Frederiksen, M. \& Dahl, K., (Eds), 1994. Birds and their ecology in the Wadden Sea. - Ophelia (Suppl.) 6, 1-357.

Gätje, C. \& Reise, K., (Eds), 1997. Ökosystem Wattenmeer: Austausch-, Transport- und Stoffumwandlungsprozesse. Springer, Heidelberg (in press).

Reise, K., 1994a. Changing life under the tides of the Wadden Sea during the 20th century. - Ophelia (Suppl.) 6, 117-125.

Reise, K., 1994b. The Wadden Sea: Museum or cradle of nature? - Wadden Sea Newsl. 1994-1, 5-8.

Rösner, H.-U., Roomen, M. van, Südbeck, P. \& Rasmussen, L. M., 1994. Migratory waterbirds in the Wadden Sea 1992/1993. - Wadden Sea Ecosyst. 2-1994, 1-72.

Stock, M., Schrey, E., Kellermann, A., Gätje, C., Eskildsen, K., Feige, M., Fischer, G., Hartmann, F., Knoke, V., Möller, A., Ruth, M., Thiessen, A. \& Vorberg, R., 1996. Ökosystemforschung Wattenmeer - Synthesebericht: Grundlagen für einen Nationalparkplan. - Schriftenr. Nationalparks Schleswig-Holsteinisches Wattenmeer 8, 1-784.

Wolff, W. J., 1992. Ecological developments in the Wadden Sea until 1990. - Publ. Ser. Neth. Inst. Sea Res. 20, 23-32. 